\title{
PRELIMINARY INVESTIGATIONS ON FLOOD SUSCEPTIBILITY MAPPING IN ANKARA (TURKEY) USING MODIFIED ANALYTICAL HIERARCHY PROCESS (M-AHP)
}

\author{
Burhan Sozer ${ }^{1}$, Sultan Kocaman ${ }^{1,}$, , Hakan A. Nefeslioglu², Orhan Firat ${ }^{3}$, Candan Gokceoglu² \\ ${ }^{1}$ Hacettepe University, Department of Geomatics Engineering, Ankara, Turkey - bsozer06@ gmail.com, \\ sultankocaman@hacettepe.edu.tr \\ ${ }^{2}$ Hacettepe University, Department of Geological Engineering, Ankara, Turkey - (hanefeslioglu, cgokce)@ hacettepe.edu.tr \\ ${ }^{3}$ General Directorate of Mapping, Ankara, Turkey - orhan.firat@hgm.msb.gov.tr
}

\section{Commission V, SS: Natural Resources Management}

KEY WORDS: Flood Mapping, Susceptibility, Hazard, Risk, Modified Analytical Hierarchy Process, Ankara (Turkey)

\begin{abstract}
:
Susceptibility mapping for disasters is very important and provides the necessary means for efficient urban planning, such as site selection and the determination of the regulations, risk assessment and the planning of the post-disaster stage, such as emergency plans and activities. The main purpose of the present study is to introduce the preliminary results of an expert based flood susceptibility mapping approach applied in urban areas in case of Ankara, Turkey. The proposed approach is based on Modified Analytic Hierarchy Process (M-AHP), which is an expert-based algorithm and provides data based modeling. The existing spatial datasets are evaluated in the decision process and the specified number of decision points according to the degree desired can be formed. The parameter priorities can be identified at the beginning of the modeling with this approach by the responsible expert. The spatial datasets used in the modeling and mapping process have been provided by the General Directorate of Mapping (HGM). Additionally, the slope gradient of topography, drainage density, and topographic wetness index of the site being one of the second derivatives of topography have been evaluated to identify the main conditioning factors controlling water accumulation on ground. Considering the uncertainties in flood hazard assessment and limitations in sophisticated analytic solutions, the proposed methodology could be evaluated to be an efficient tool to detect the most influential parameters representing the flood vulnerability and assessing the mitigation applications in urban environment.
\end{abstract}

\section{INTRODUCTION}

\subsection{Problem Definition}

The increasing number of disaster events has drawn the attention of researchers and government agencies for better analysis of the causes and implementation of new policies and strategies. Improved disaster-risk management and resilience are important at local and global levels and United Nations (UN) adopted 17 Goals to be achieved until the year 2030, on September 25th, 2015 at the Summit, to end poverty, protect the planet and ensure prosperity for all. The effect of the disasters can be more severe in urban areas due to economic losses, such as damages in infrastructure and other constructions, and even loss of lives in some cases.

Floods constitute one of the most destructive natural hazards worldwide (Adhikari et al., 2010). According to the Centre for Research on the Epidemiology of Disasters report (CRED, 2018) the top disaster occurred between 2016-2017 is flood; the rank of the disaster in 2017 is declared to be the second after storms in the same report. Additionally, the number of deaths and affected people due to the floods occurred in 2017 only are given as more than 3000 and 50 million, respectively (CRED, 2018). Similar, increasing trends are also observed in Turkey. According to the statistics given by Gökçe et al. (2008), floods become the third important natural disaster in Turkey after landslides and earthquakes. However, even in the capital city of Turkey, Ankara, five flood events were encountered only in the first half of 2018. It is obvious that depending on the climate change the frequencies of flood events are expected to be increased in the next decade in Turkey as well. It is crucial to perform necessary preparatory mitigation works before the disaster happens. In order to plan necessary mitigation applications, flood susceptibility maps may constitute indispensable information which should have to be taken into account by decision makers (Perucca and Angilieri, 2011; Scheuer et al., 2013; Cunha et al., 2017). Thus, the aim of this study is to introduce the preliminary results of the expert based flood susceptibility mapping approach applied in urban areas of Ankara (Turkey).

\subsection{Methodology \& Related Literature}

Flood evaluation techniques can be classified simply as follows: (i) flood forecasting methods including hydrologic and hydraulic models; (Kellens et al., 2013; Gallina et al., 2016; Teng et al., 2017) and (ii) flood susceptibility assessments including analytical evaluations of geomorphometric, geologic and environmental factors (Morelli et al., 2014; Wang et al., 2015; Khosravi et al., 2016; Chapi et al., 2017; Gonzalez-Arqueros et al., 2018). The main limitation for hydrologic and hydraulic models is the lack of appropriate data for the region to be investigated in data sparse areas (Komi et al., 2017). On the other hand, flood susceptibility assessments are promoted to be a lowcost tool for evaluation of flood vulnerability (Cunha et al., 2017). In this study, flood susceptibility assessments of the urban area of Ankara were carried by implementing a decision support system namely Modified Analytical Hierarchy Process (M-AHP) which was introduced by Nefeslioglu et al. (2013).

\subsection{Paper Outline}

The investigations were carried out in five stages: (i) The first stage is the data production; the data produced and gathered in this stage includes vector and photogrammetric data sets. (ii) In the second stage, the conditioning factors of flood event were evaluated; subsequently. (iii) In the third stage the basics of the decision support system, M-AHP implemented in this study was given briefly. (iv) M-AHP application for flood susceptibility assessment was carried out in the Geographic Information

\footnotetext{
${ }^{*}$ Corresponding author
} 
System (GIS) analyses section, and then at the last stage of the study (v) a decision support was provided for the flood susceptibility zonation in the urban area of Ankara.

\section{MATERIALS AND METHODS}

\subsection{Photogrammetric Datasets}

Aerial photogrammetric flight missions for mapping purposes are being carried out regularly in Turkey since 1936 by General Directorate of Mapping (HGM) and General Directorate of Land Registry and Cadastre (GDLRC). Although analog large-format cameras were in use for long time, they have been replaced with digital large-format cameras in 2008. In this study, aerial photogrammetric images acquired in 2008 by HGM using Ultracam-X camera and in 2015 using Ultracam Eagle camera, both from Vexcel Imaging (2018), have been used together with exterior and interior orientation parameters for digital surface model (DSM), digital terrain model (DTM) and orthoimage mosaic generation purposes. Although other flight datasets of the study area, including the ones from 1936, exist, only 2008 and 2015 images with $30 \mathrm{~cm}$ ground sampling distance (GSD) have been used for preliminary investigations. These datasets have later been used for visualization of the area. On the other hand, they will be used for higher resolution susceptibility mapping of smaller areas and detecting changes in land use and land cover for further investigations.

The topography has been formed by surface reconstruction from manually measured contour lines and interpolating into a grid DTM. Derivatives of the topography, i.e. flow accumulation, slope gradient, and topographic wetness index (TWI) have been computed using this DTM.

\subsection{Vector Data}

The vector datasets used in this study have been taken from Topographic Vector Database (TOPOVT), which contain 352 types of features covering seamlessly and homogeneously whole Turkey and produced by HGM. The data have been produced from the latest aerial images (i.e. from year 2015) by manual interpretation of stereo images and complementary terrestrial measurements. Semantic data are also stored implicitly in this dataset. For the investigations presented here, only the vector layers related to rivers, lakes, seasonal and dry drainage channels have been employed.

\subsection{Conditioning Parameters}

The parameters governed the flood process were evaluated by considering the conceptual infiltration, surface runoff, and accumulation propositions. These propositions can be given simply as follows:

$\mathrm{R}_{1}$ : if "low infiltration" than "high surface runoff" or "high accumulation"

$\mathrm{R}_{2}$ : if "high infiltration" than "low surface runoff" or "low accumulation"

$\mathrm{R}_{3}$ : if "low surface runoff" than "high infiltration" or "high accumulation"

$\mathrm{R}_{4}$ : if "high surface runoff" than "low infiltration" or "low accumulation"

$\mathrm{R}_{5}$ : if "low accumulation" than "high infiltration" or "high surface runoff"

R6: if "high accumulation" than "low infiltration" or "low surface runoff"
As can be seen from the propositions given simply above, the flood susceptibility evaluation is a multi-dimensional and multicriteria problem. The topographic, hydro-topographic, geologic, and environmental parameters which are considered to be indirectly govern the physical processes given above were evaluated. The topographic altitude and slope gradient are the first group of geomorphometric factors considered in this study. Accordingly; the flood susceptibility is expected to be high at the lower topographic altitudes while the susceptibility should be high at the lower values of slope gradient. In order to evaluate the hydrology, the hydro-topographic parameters flow accumulation, distance to both permanent and dry river channels, and topographic wetness index were considered. Flow accumulation can be defined as the number in a given cell which indicates the number of cells upstream from that cell (Kennedy, 2009); that means depending on the increasing of flow accumulation value, the flood susceptibility is expected to be increased. It is obvious that both permanent and dry river channels constitute crucial inputs of the flood susceptibility assessment; as expected depending on the decreasing of the distance to river channel, the flood susceptibility should be increased. The topographic wetness index indicates depressions in general where the water can accumulate, and the soil can be more saturated (Wilson and Gallant, 2002). Hence, depending on the increasing of this index, the flood susceptibility also increases. The lithology was considered as the geologic factor in this study. The lithology data was provided from the Earth Science Data Portal of the General Directorate of Mineral Research and Exploration (Akbaş et al., 2002). The relative permeabilities of major rock types were evaluated (Bell, 2007) during the assessment of the lithology parameter in this study. Accordingly, depending on the increasing of the permeability, the flood susceptibility is expected to be decreased. The last parameter investigated in this study is the land cover which was evaluated as the environmental factor. In order to produce the land cover of the region investigated, a supervised classification was performed by using the Landsat 8 imagery acquired on August 24, 2018. As a result of this classification procedure, six types of land cover were differentiated. The settlement and industrial areas are assumed to be practically impermeable that means the flood susceptibility should be the maximum in these areas.

\subsection{Modified Analytical Hierarchy Process (M-AHP)}

The Modified Analytical Hierarchy Process (M-AHP) is a modified version of the conventional AHP which was formerly proposed by Saaty (1980). The modification actually compensates the expert subjectivity particularly encountered in the factor comparisons. The differences between the M-AHP and the conventional AHP are given by Nefeslioglu et al. (2013) as follows: (i) The preparation of the factor comparison matrix performed in the second stage of the conventional AHP; and (ii) the evaluation of the importance distributions of the conditioning factors on the decision points.

In order to perform M-AHP analyses, to define the flood susceptibility in Ankara urban area, the first stage is the assignment of the parameters scores which are evaluated in further matrix calculations. The scores of the conditioning factors were assigned by the responsible expert by considering mainly the discussions given in the previous section (Table 1). The higher score in Table 1 represents the higher flood susceptibility. M-AHP analyses were carried out by using the M-AHP software running on a GIS environment developed by Netcad (Avdac et al., 2014; Sezer et al., 2017). 
Table 1. The parameters, their classes, and the parameter scores given by the expert for flood susceptibility.

\begin{tabular}{|c|c|}
\hline \multicolumn{2}{|l|}{ Parameter } \\
\hline \multicolumn{2}{|l|}{ Flow Accumulation (\# of grid cells) } \\
\hline Class & Score \\
\hline$<5000$ & 1 \\
\hline $5000-15000$ & 3 \\
\hline $15000-25000$ & 5 \\
\hline $25000-35000$ & 7 \\
\hline $35000-45000$ & 9 \\
\hline $45000-55000$ & 13 \\
\hline$>55000$ & 17 \\
\hline \multicolumn{2}{|l|}{ Slope gradient (degree) } \\
\hline Class & Score \\
\hline$<3$ & 13 \\
\hline $3-5$ & 11 \\
\hline $5-7$ & 9 \\
\hline $7-9$ & 7 \\
\hline $9-11$ & 5 \\
\hline $11-13$ & 3 \\
\hline$>13$ & 1 \\
\hline \multicolumn{2}{|l|}{ Topographic altitude (m) } \\
\hline Class & Score \\
\hline$<900$ & 9 \\
\hline $900-1000$ & 7 \\
\hline $1000-1100$ & 5 \\
\hline $1100-1200$ & 3 \\
\hline$>1200$ & 1 \\
\hline \multicolumn{2}{|l|}{ Distance to permanent river (m) } \\
\hline Class & Score \\
\hline$<20$ & 15 \\
\hline $20-40$ & 13 \\
\hline $40-60$ & 11 \\
\hline $60-80$ & 9 \\
\hline $80-100$ & 7 \\
\hline $100-120$ & 5 \\
\hline $120-140$ & 3 \\
\hline$>140$ & 1 \\
\hline \multicolumn{2}{|l|}{ Distance to dry drainage (m) } \\
\hline Class & Score \\
\hline$<20$ & 11 \\
\hline $20-40$ & 9 \\
\hline $40-60$ & 7 \\
\hline $60-80$ & 5 \\
\hline $80-100$ & 3 \\
\hline$>100$ & 1 \\
\hline \multicolumn{2}{|l|}{ Land Cover } \\
\hline Class & Score \\
\hline Wetland & 13 \\
\hline Barren & 7 \\
\hline Industry & 11 \\
\hline Settlement & 11 \\
\hline Green field & 5 \\
\hline Road & 11 \\
\hline \multicolumn{2}{|l|}{ Topographic Wetness Index } \\
\hline Class & Score \\
\hline$<495$ & 1 \\
\hline $495-1650$ & 5 \\
\hline $1650-5000$ & 9 \\
\hline $5000-45000$ & 11 \\
\hline $45000-132000$ & 13 \\
\hline$>132000$ & 15 \\
\hline \multicolumn{2}{|l|}{ Geology; litology } \\
\hline Class & Score \\
\hline Water body & 11 \\
\hline Basalt, split, andesite & 5 \\
\hline Undifferentiated Quaternary & 1 \\
\hline Continental clastics & 3 \\
\hline Lacustrine limestone, marn, shale & 9 \\
\hline Neritic limestone & 5 \\
\hline
\end{tabular}

\begin{tabular}{lc} 
Carbonates and clastics & 5 \\
Pelagic limestone & 7 \\
Metamorphic rocks; schist, phyllite, marble, & 11 \\
meta-basalt & 9 \\
Ophiolitic melange & 5 \\
Basalt & 7 \\
Pyroclastic rocks & 5 \\
\hline Undifferentiated volcanic rocks & \\
\hline
\end{tabular}

\section{RESULTS \& DISCUSSION}

As a result of the analyses, the importance percentages on the decision points; low, moderate, and high were obtained. Considering the third decision point; high was selected to be mapped. The percentage values of the decision high were reclassified into five flood susceptibility classes by considering equal intervals. As a consequence, the flood susceptibility map of Ankara urban area was produced (Figure 1).

The most critical locations with respect to the flood susceptibility are observed as mature width alluvial valley floors of the districts Yenimahalle and Etimesgut and younger narrow alluvial valley bottoms of the district Cankaya. The results of these locations are also represented by overlaying on the DTM (Figure 2). Figure 3 depicts a zoomed view of the resulting image (given in Figure 2a) and respective orthoimage, both overlaid on the DTM. According to the visual inspections the results of the flood susceptibility assessments, it is revealed that the high and very high flood susceptibility classes logically match well with the DTM details.

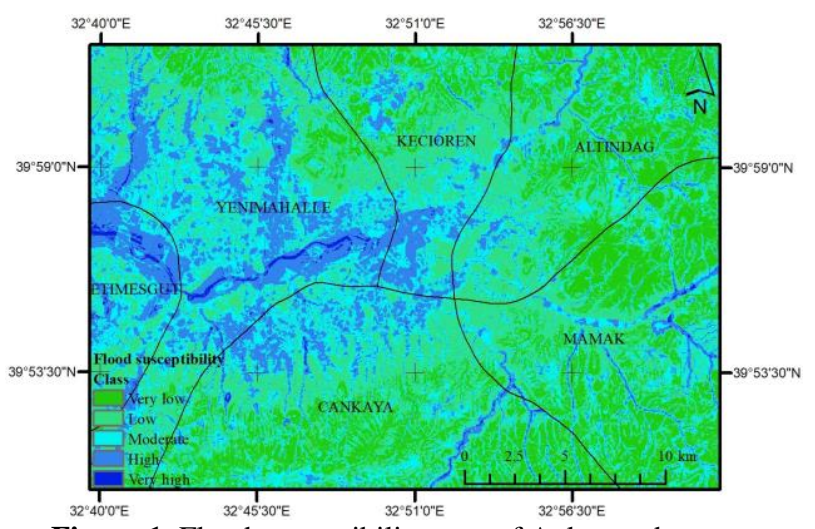

Figure 1. Flood susceptibility map of Ankara urban area.

\section{CONCLUSIONS \& FUTURE WORK}

The results represented in the present study were produced in medium scale in particular. The preliminary findings are appraised to be promising results for the future work. It is obvious that depending on the increment in working scale as well as the data resolution, more precise outputs can be acquired. Moreover, the satellite optical and radar images particularly having frequent revisit times e.g. Sentinel $1 \& 2$ can be implemented to improve and validate the results of such expert models after intrinsic flood events. 

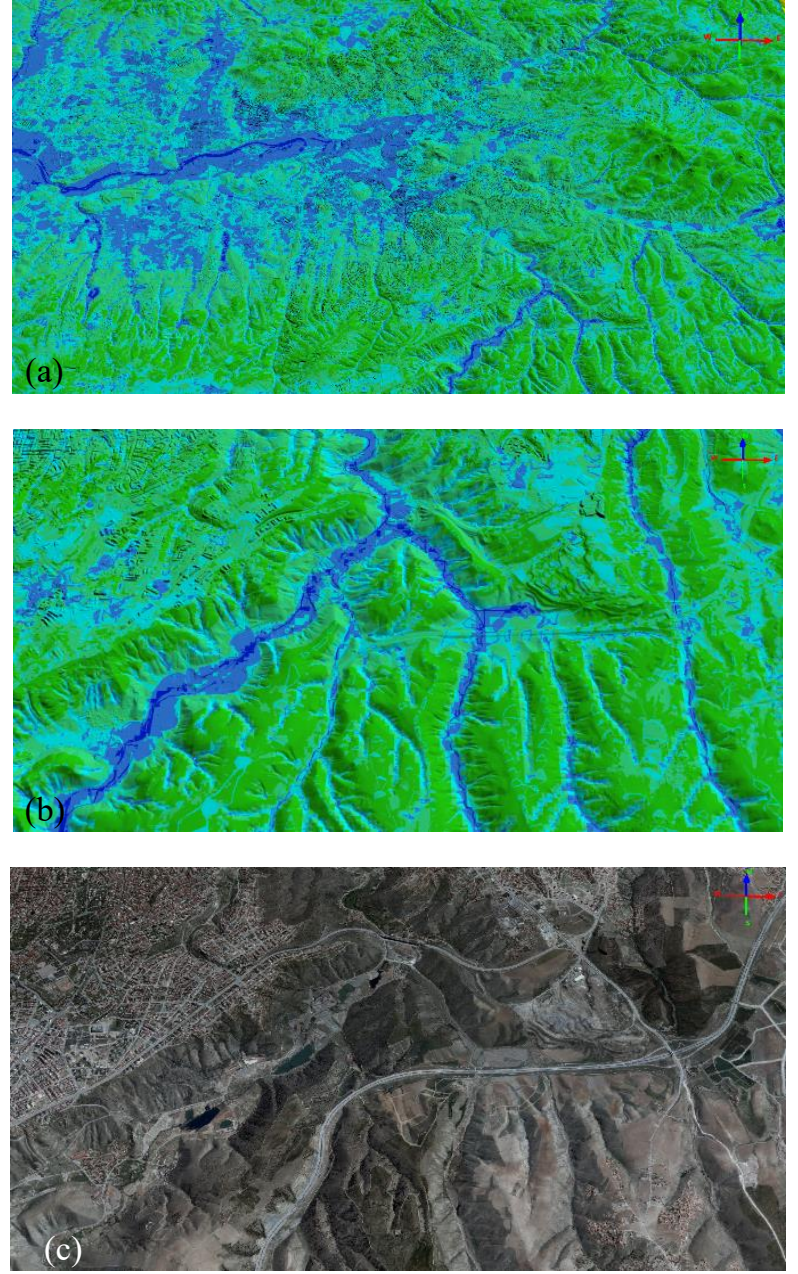

Figure 2. The critical locations with respect to flood susceptibility represented with the DTM; (a) mature width alluvial valley floors of the districts Yenimahalle and Etimesgut; (b) younger narrow alluvial valley bottoms of the district Cankaya; (c) orthoimage of (b) overlayed on the DTM.
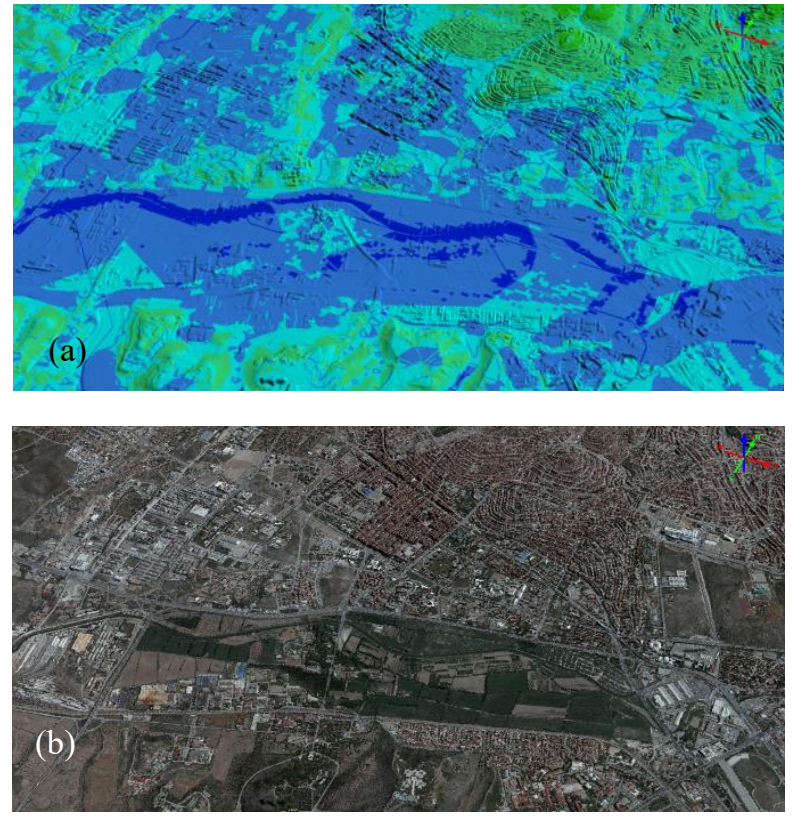

Figure 3. (a) A zoomed view from Figure 2a; and (b) corresponding orthoimage.

\section{ACKNOWLEDGEMENTS}

The authors gratefully acknowledge the continuous support of General Directorate of Mapping (HGM) within the cooperation framework on "Disaster Studies and Photogrammetry" between Hacettepe University and HGM. Many thanks to the Netcad Company Team for provisioning the software used for M-AHP.

\section{REFERENCES}

Adhikari, P., Hong, Y., Douglas, K.R., Kirschbaum, D.B., Gourley, J., Adler, R., Brakenridge, G.R., 2010. A digitized global flood inventory (1998-2008): compilation and preliminary results. Natural Hazards 55, 405-422.

Akbaş, B., Akdeniz, N., Aksay, A., Altun, İ., Balcı, V., Bilginer, E., Bilgiç, T., Duru, M., Ercan, T., Gedik, İ., Günay, Y., Güven, İ.H., Hakyemez, H. Y., Konak, N., Papak, İ., Pehlivan, Ş., Sevin, M., Şenel, M., Tarhan, N.,Turhan, N., Türkecan, A., Ulu, Ü., Uğuz, M.F., Yurtsever, A. ve diğerleri, 2002. Türkiye Jeoloji Haritası. Maden Tetkik ve Arama Genel Müdürlüğü Yayını, Ankara, Türkiye. http://yerbilimleri.mta.gov.tr/ (05/09/2018)

Avdac, D., Poyraz, M., Nefeslioglu, H.A., Sezer, E.A., Toptas, T.E., Celik, D., Orhun, K., Osna, T., Ak, S., Gokceoglu, C., 2014. Modified analytical hierarchy process (M-AHP) based river-line flood hazard assessment module running on GIS: Netcad architect environment. EGU General Assembly 2014, Wien, Austria. Vol. 16, EGU2014-2348.

Bell, F.G., 2007. Basic Environmental and Engineering Geology. Whittles Publishing, CRC Press, Taylor \& Francis Group, Scotland, $332 \mathrm{p}$.

Chapi, K., Singh, V.P, Shirzadi, A., Shahabi, H., Bui, D.T., Pham, B.T., Khosravi, K., 2017. A novel hybrid artificial intelligence approach for flood susceptibility assessment. Environmental Modelling \& Software 95, 229-245.

Cunha, N., Magalh, M., Domingos, T., Abreu, M., Küpfer, C., 2017. The land morphology approach to flood risk mapping: an application to Portugal. Journal of Environmental Management 193, 172-187.

CRED, 2018. Natural Disasters 2017. EM-DAT file dated 02/07/2018. https://cred.be/sites/default/files/adsr_2017.pdf $(03 / 09 / 2018)$.

Gallina, V., Torresan, S., Critto, A., Sperotto, A., Glade, T., Marcomini, A., 2016. A review of multi-risk methodologies for natural hazards: consequences and challenges for a climate change impact assessment. Journal of Environmental Management 168, 123-132.

González-Arquerosa, M.L., Mendoza, M.E., Bocco, G., Castillo, B.S., 2018. Flood susceptibility in rural settlements in remote zones: The case of a mountainous basin in the Sierra-Costa region of Michoacán, Mexico. Journal of Environmental Management 223, 685-693.

Gökçe, O., Özden, Ş. ve Demir, A. 2008. Türkiye'de Afetlerin Mekansal ve İstatistiksel Dağılımı Afet Bilgileri Envanteri. Bayındırlık ve İskân Bakanlığı, Ankara. (in Turkish)

Kellens, W., Terpstra, T., De Maeyer, P., 2013. Perception and communication of flood risks: a systematic review of empirical research. Risk Analysis 33, 24-49. 
Kennedy, M., 2009. Introducing Geographic Information Systems with ArcGIS: A Workbook Approach to Learning GIS. John Wiley \& Sons, Inc., New Jersey, 571 p.

Khosravi, K., Pourghasemi, H.R., Chapi, K., Bahri, M., 2016. Flash flood susceptibility analysis and its mapping using different bivariate models in Iran: a comparison between Shannon's entropy, statistical index, and weighting factor models. Environmental Monitoring and Assessment 188 (656), $21 \mathrm{p}$.

Komi, K., Neal, J., Trigg, M.A., Diekkrüger, B., 2017. Modelling of flood hazard extent in data sparse areas: a case study of the Oti River basin, West Africa. Journal of Hydrology: Regional Studies 10, 122-132.

Morelli, S., Battistini, A., Catani, F., 2014. Rapid assessment of flood susceptibility in urbanized rivers using digital terrain data: Application to the Arno river case study (Firenze, northern Italy). Applied Geography 54, 35-53.

Nefeslioglu, H.A., Sezer, E.A., Gokceoglu, C., Ayas, Z., 2013. A Modified Analytical Hierarchy Process (M-AHP) approach for decision support systems in natural hazard assessments. Computers \& Geosciences 59, 1-8.

Perucca, L.P., Angilieri, Y.E., 2011. Morphometric characterization of del Molle Basin applied to the evaluation of flash floods hazard, Iglesia Department, San Juan, Argentina. Quaternary International 233, 81-86.

Saaty, T.L., 1980. The Analytic Hierarchy Process. McGraw-Hill International Book Co., NewYork, 287 p.

Scheuer, S., Haase, D., Meyer, V., 2013. Towards a flood risk assessment ontology - knowledge integration into a multi-criteria risk assessment approach. Computers, Environment and Urban Systems 37, 82-94.

Sezer, E.A., Nefeslioglu, H.A., Osna, T., 2017. An expert-based landslide susceptibility mapping (LSM) module developed for Netcad Architect Software. Computers \& Geosciences, 98, 2637.

Teng, J., Jakeman, A.J., Vaze, J., Croke, B.F.W., Dutta, D., Kim, S., 2017. Flood inundation modelling: a review of methods, recent advances and uncertainty analysis. Environmental Modelling \& Software 90, 201-216.

Vexcel Imaging, 2018. https://www.vexcel-imaging.com/ $(05 / 09 / 2018)$

Wang, Z., Lai, C., Chen, X., Yang, B., Zhao, S., Bai, X., 2015. Flood hazard risk assessment model based on random forest. Journal of Hydrology 527, 1130-1141.

Wilson, J.P., Gallant, J.C., 2000. Terrain analysis principles and applications. John Wiley and Sons, Inc., Canada, 479 p. 